\title{
Rainfall runoff estimation using GIS and SCS-CN method for awash river basin, Ethiopia
}

\begin{abstract}
Understanding hydrological behavior is an important part of effective watershed management and planning. Runoff resulted from rainfall is a component of hydrological behavior that is needed for efficient water resource planning. In this paper, GIS based SCS$\mathrm{CN}$ runoff simulation model was applied to estimate rainfall runoff in Awash river basin. Global Curve Number (GCN250), Maximum Soil Water Retention (S) and Rainfall was used as an input for SCS-CN runoff simulation model. The final surface runoff values for the Awash river basin were generated on the basis of total annual rainfall and maximum soil water retention potential (S) of the year 2020. Accordingly, a runoff variation that range from $83.95 \mathrm{~mm} /$ year to a maximum of $1,416.75 \mathrm{~mm} /$ year were observed in the study region. Conversely, recently developed Global Curve Number (GCN250) data was tested with Pearson correlation coefficient to be used as an input for SCS-CN runoff simulation model. In doing so, predicted runoff generated in SCS-CN using GCN250 as a model input was validated with observed runoff obtained from station gauges in the study region. The results of validation show that, predicted runoff was well correlated with observed runoff with correlation coefficient of 0.9253 . From this stand point, it is observed that the new GCN250 data can be used as an input for SCS-CN model to estimate rainfall runoff at basin level. Furthermore, correlation analysis was performed to explain the relationship between mean annual rainfall and surface runoff. The relationship between these two variables indicates a strong linear relationship with correlation coefficient of 0.9873 .
\end{abstract}

Keywords: global curve number (GCN250), soil conservation service-curve number (SCS-CN), maximum soil water retention (S), runoff, geographic information system (GIS)
Volume 5 Issue I - 202 I

\section{Shimelis Sishah}

School of Social Science and Humanities, Arsi University, Ethiopia

Correspondence: Shimelis Sishah, School of Social Science and Humanities, Arsi University, PO box 09, Bokoji, Ethiopia, Tel +25192326006I, E-mail shimelisgis20I@gmail.com

Received: March 13, 2021 | Published: March 22, 202

\section{Introduction}

Surface runoff at watershed scale significantly affects agriculture, environment and the availability of flood potential. ${ }^{1}$ Watershed runoff determines the hydraulic properties, soil erosion condition and even the potential yield of water resources within a given watershed. ${ }^{2}$ Runoff from a watershed can be measured daily, monthly or annually depending on rainfall, infiltration rate and the characteristics of watershed. ${ }^{3}$ Accurate estimation of surface runoff helps in designing irrigation schema, waterways, water harvesting and ground water resource management. ${ }^{4}$ Accurate estimation of surface runoff can be achieved using hydrological modeling that takes into account the impacts of climate and land use on surface water balance. ${ }^{3}$ Understanding rainfall and runoff is essential for the assessment of water availability. Correct runoff assessment is done for useful control and improvement of water resources. ${ }^{5}$ Evaluation of water availability with the aid of an understanding of rainfall and runoff is vital. Hydrometeorological and hydrological statistics are an important position within the evaluation of supply water accessibility for the making plans and layout of synthetic recharge systems. ${ }^{6}$ Surface runoff modeling is used to understand water availability, catchment yield and change over time in a given hydrological unit. ${ }^{7}$ Although rainfall runoff understanding is essential in hydrological applications, modeling surface rainfall runoff is difficult. ${ }^{8}$

Numerous methods to compute runoff from a rainfall event have been developed. One of the most famous methods for predicting the surface runoff extent from a small watershed due to a rainstorm is the soil conservation service curve number (SCS-CN) method, now called the Natural Resource Conservation Service (NRCS)-CN method developed by the USDA-soil conservation service. ${ }^{9}$ The SCS-CN simulation model combines the parameters of the watershed with the climatic elements in a single entity referred to as the curve number $(\mathrm{CN})$. A high $\mathrm{CN}$ shows low infiltration and excessive runoff, at the same time as a low $\mathrm{CN}$ implies excessive infiltration and low runoff. The SCS-N technique presents adequate consequences without the use of complicated statistics. ${ }^{10,11}$ Supporting this statement, ${ }^{12}$ employed the SCS-CN approach for simulating the once-a-year depth of runoff over an ungauged catchment of Vindhyachal region. They revealed that the SCS-CN approach can be used efficiently to estimate the depth of runoff when there's no good enough hydrological data. In addition, ${ }^{13}$ computed the runoff over a watershed inside the loess plateau of china with the SCS-CN approach and stated that the SCS$\mathrm{CN}$ is a powerful and successful approach for estimating runoff.

Runoff information at watershed scale is essential for the development of watershed planning for natural resource conservation. A number of hydrological models has been developed and used over years to predict the runoff information in different hydrological units. In recent years, SCS-CN number method has been widely used model to estimate runoff from spatial data. This method requires the property of soil permeability, land use, and Antecedent soil moisture condition prior to the storm event. Although SCS-CN method can simulate rainfall runoff from soil, land use, and Antecedent soil moisture condition effectively, curve number $(\mathrm{CN})$ generation from land use and hydrological soil group at basin scale requires intensive computational tasks. However, ${ }^{14}$ produced Global Curve Number (GCN250) with a spatial resolution of $250 \mathrm{~m}$ at global scale. This product can resolve intensive computational tasks in generating curve 
number at basin level. Therefore, the focus of this research work was testing GCN250 data to be used as an input for SCS-CN runoff simulation model at basin scale.

\section{Study area and dataset}

\section{Study area}

Awash River Basin is one of the most utilized basin on the basis of Awash river relative to the rest of twelve main basins of Ethiopia. ${ }^{15}$ The geographic location of the Awash River basin is between $7^{\circ}-10^{\circ} \mathrm{N}$ latitudes and $38^{\circ}-41^{\circ} \mathrm{E}$ of longitudes. The river basin elevation ranges from $250 \mathrm{~m}$ at Afar depression to $3000 \mathrm{~m}$ of Addis Ababa highlands above mean sea level. ${ }^{16}$ According to Awash river basin is bounded to the west by the Blue Nile, to the southeast by the Rift Valley lakes and to the south by Wabeshebele. Awash River basin covers an area of $112,000 \mathrm{KM} 2$ and the water volume of the River basin was estimated at around 4.9 billion cubic meters ${ }^{17}$ Figure 1 .

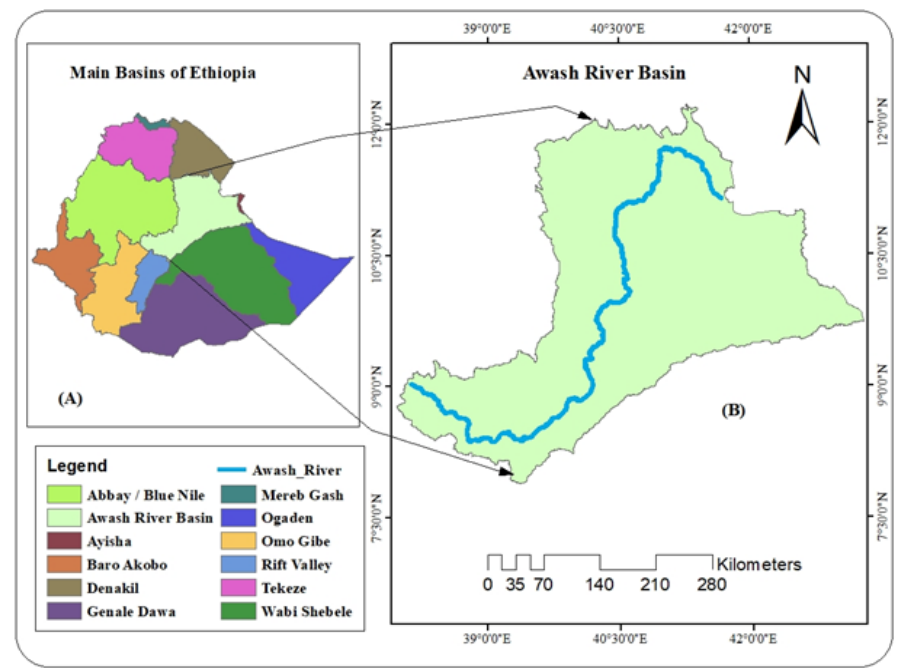

Figure I Geographic location.

\section{Dataset}

\section{CHIRPS rainfall data}

Climate Hazard Group Infrared Precipitation (CHIRPS) data is a long-term temporal coverage data (1981 to present). It provides precipitation data at global scale with $0.05 \times 0.05$ degrees which is approximately five kilometers $(5 \mathrm{~km}) .^{18}$ For this research work, CHIRPS data of the year 2020 was downloaded from (https:// earlywarning.usgs.gov/fews) site freely. CHIRPS data archive provides rainfall data on daily, monthly and annual basis. For this study, the rainfall data of the twelve months was downloaded and processed to obtain the total annual rainfall of the year 2020 .

\section{Global Curve Number (GCN) data}

Global Curve Number (GCN) is valuable data for rainfall runoff modelling. The first grided curve number data at global scale was created by. ${ }^{14}$ The data was generated from ESA land cover map onward 2015 and Hydrological soil group data based on USDA curve number. The GCN data represent the curve number under wet, dry, and average conditions with $250 \mathrm{~m}$ spatial resolution. For this project work, GCN with $250 \mathrm{~m}$ spatial resolution was downloaded from (https://figshare. com/) website and clipped with study area extent.

\section{Methods}

\section{SCS-CN runoff simulation model}

SCS-CN model has been widely used model over years for runoff simulation. ${ }^{11}$ The model is compatible with remote sensing data such as land use and soil type. Curve number $(\mathrm{CN})$ quantifies the impact of soil and land use on rainfall runoff process. The SCS runoff model is based on the $\mathrm{CN}$ information and the model equation is given in equation (1).

$$
Q=\frac{(P-\ddot{\mathrm{e}} S)^{2}}{P+(\Phi-) S}
$$

Where, $Q$ is direct runoff, $P$ is total rainfall, $\lambda$ is initial abstraction, and $S$ is maximum soil water retention Initial abstraction coefficient ( $\lambda$ ) in equation (1) takes into account the infiltration, interception, and canopy content during early rainfall event. ${ }^{13,19}$ indicated that initial abstraction coefficient $(\lambda)$ can vary between zero and infinity ( 0 and $\infty)$. However, ${ }^{20}$ noted that initial abstraction coefficient $(\lambda)$ is 0.2 for the general use of runoff simulation. Maximum soil water retention potential $(S)$ can be calculated from dimensionless curve number $(\mathrm{CN})$ as shown in equation (2).

$$
S=\frac{25400}{C N}-254
$$

Where, $C N$ represents runoff potential which is determined by Antecedent Soil Moisture (AMC) condition. AMC describes prestorm condition of the basin wetness and soil storage capacity. Three levels of AMC are identified, AMC I for wet condition, AMC II for normal (average) condition and AMC III for heavy rainfall condition. ${ }^{20}$ For rainfall runoff modelling purpose, $\mathrm{CN}$ value derived as a function AMC II for average condition (water) was applied for this project work. The following table (Table 1) depicts Antecedent soil moisture class for five-day rainfall.

Table I Five-day Antecedent Moisture Conditions

\begin{tabular}{llll}
\hline $\begin{array}{l}\text { AMC } \\
\text { group }\end{array}$ & $\begin{array}{l}\text { Soil } \\
\text { characteristics }\end{array}$ & \multicolumn{2}{c}{ Five-day antecedent rainfall $(\mathbf{m m})$} \\
\hline & & Dormant season & Growing season \\
\hline I & Wet condition & $<13$ & $<36$ \\
II & $\begin{array}{l}\text { Average } \\
\text { condition } \\
\text { Heavy rainfall } \\
\text { condition }\end{array}$ & $13-28$ & $36-53$ \\
III & $>28$ & $>53$ \\
\hline
\end{tabular}

Curve numbers (CNI and CNIII) can be calculated from average Antecedent (AMC II) conditions using equation (3 and 4).

$$
\begin{aligned}
& C N(I)=\frac{C N(I I)}{2.281-0.0128 C N(I I)} \\
& C N(I I I)=\frac{C N(I I)}{0.427-0.00573 C N(I I)}
\end{aligned}
$$

\section{Validation}

The effectiveness of GCN250 data for rainfall runoff simulation was tested and quantified with Pearson correlation coefficient (R). The relationship between predicted runoff from GCN250 using SCS-CN 
simulation model was correlated with observed runoff obtained from station gauges of Awash river basin. The following equation (equation 6) can be applied to calculate coefficient of determination (R)

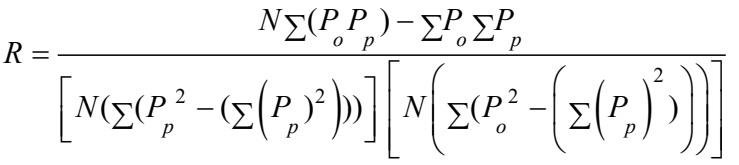

\section{Results and discussion}

\section{Soil conservation service curve number (SCS-CN)}

Curve number $(\mathrm{CN})$ values for each cell was obtained from Global Curve Number which was developed on the basis of Average Antecedent Moisture Condition (AMC II), hydrological soil group, and land use land cover. As indicate in Figure 2 (B) the values of $\mathrm{CN}$ II ranges from 60 in the basin highland areas to 94 in flat regions of Afar. Furthermore, CNI and CNIII are calculated from AMC II as shown in equation ( 3 and 4). As shown in Figure 2 (A \& C) the lowest $\mathrm{CN}$ values are 40 and 85 , whereas the highest $\mathrm{CN}$ values were 85 and 98 for CNI and CNIII respectively. The values of these CN (CNI, CNII, and CNIII) emphasize that most part of Awash river basin is characterized by less vegetation coverage which trigged high level surface rainfall runoff rate.

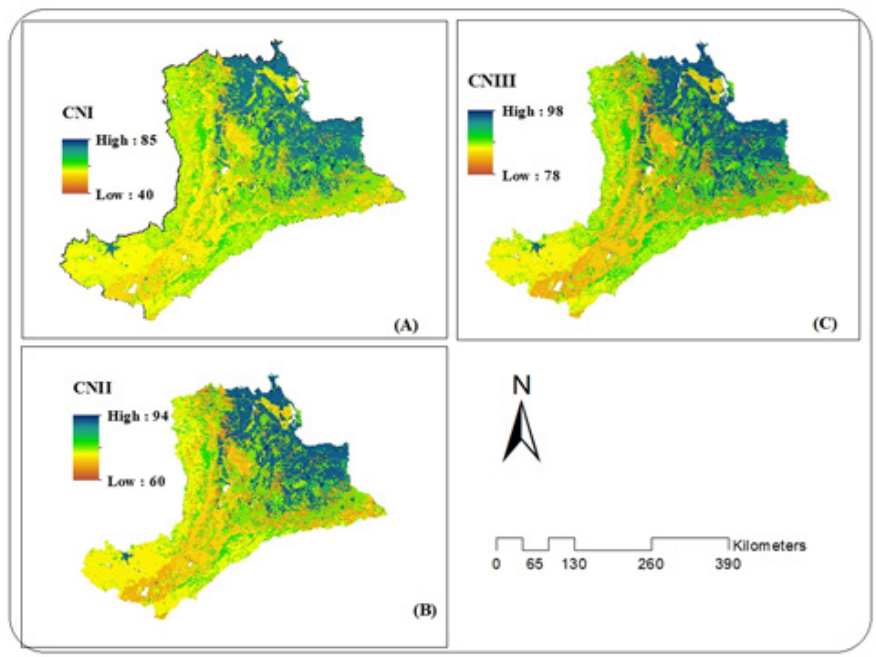

Figure 2 SCS- curve numbers for Awash river basin.

\section{Maximum soil water retention potential (S)}

Maximum soil water retention potential (S) can be calculated from CN II using equation (2). The formula in equation (2) was executed on raster calculator tool in ArcGIS environment. As indicated in Figure (3), the values of Maximum soil water retention potential (S) range from 16 at the north western part to 169 at the central and southern part of the Awash river basin. The highest values of $\mathrm{S}$ are located at areas covered with agriculture and vegetation, whereas the lowest $\mathrm{S}$ values are located at areas covered with bare land or little vegetation and built-up.

\section{Rainfall map}

Mean monthly rainfall data of CHIRPS was downloaded independently for Awash river basin. Monthly rainfall of the study region first needs to be computed for SCS-CN rainfall runoff simulation input. Therefore, rainfall data of each month was added together in raster calculator of ArcGIS environment to obtain the total annual rainfall for Awash river basin. Total annual rainfall of the year 2020 for study region was also developed in ArcMap (10.8 version). In Figure 4, it known that the total annual rainfall of the Awash river basin varies from $146.73 \mathrm{~mm}$ to $1490.99 \mathrm{~mm}$ in 2020. The highest rainfall was observed at the south eastern highlands of Addis Ababa and the lowest rainfall was shown at northern part of Afar depression in Figure 3, 4.

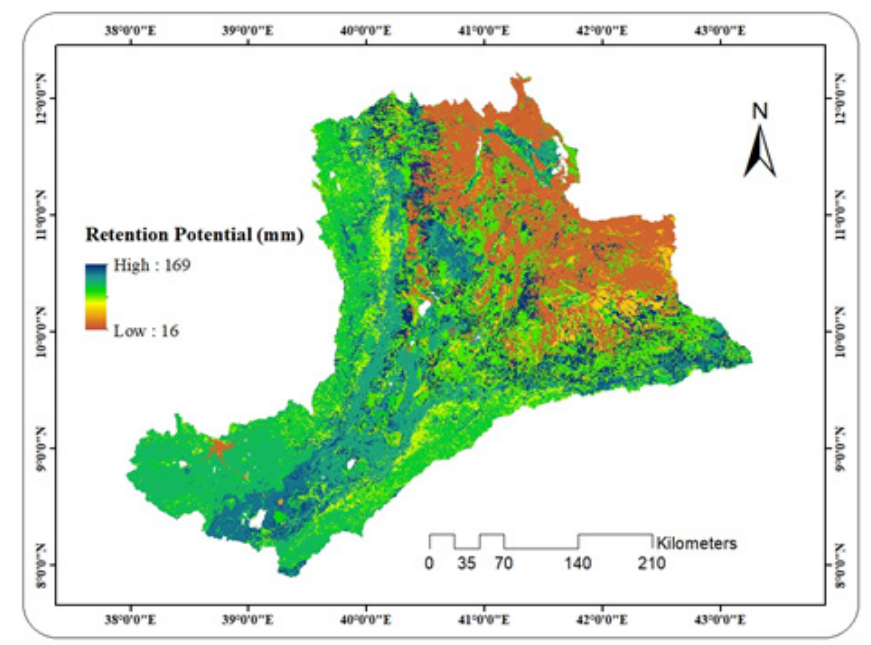

Figure 3 Maximum soil water retention potential.

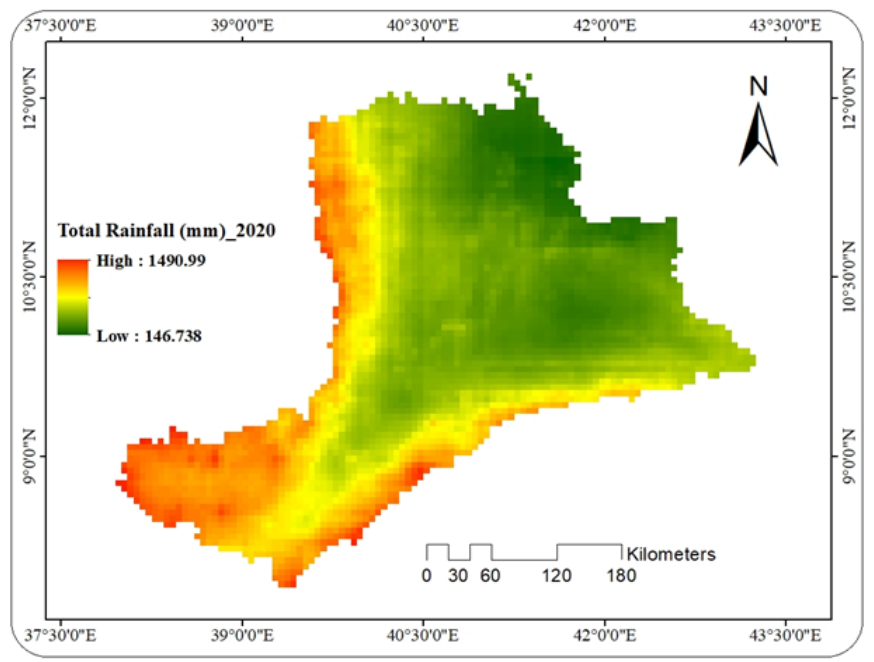

Figure 4 Total annual rainfall.

\section{Runoff}

Soil Conservation Service-Curve Number (SCS-CN) rainfall runoff was generated on the basis of maximum soil water retention potential (S) and mean annual rainfall (P). These values are used as an input for GIS based SCS-CN runoff simulation model. As shown in Figure (5), a variation that range from $83.95 \mathrm{~mm} /$ year to a maximum of $1,416.75 \mathrm{~mm} /$ year was observed due to rainfall variability across the study region and curve number resulted from land use land cover and hydrological soil group. As a result, areas with poor retention potential such as built-up are exposed to high runoff rate. Similarly, the highland areas of the river basin with fine soil particles are also 
exposed to high runoff volume Figure 5. On the other hand, areas covered with agriculture and vegetation has shown high retention potential and resulted low runoff volume. Therefore, high runoff rate in the study region was shown at the south western part, whereas the entire study region was covered with very low and medium runoff volume.

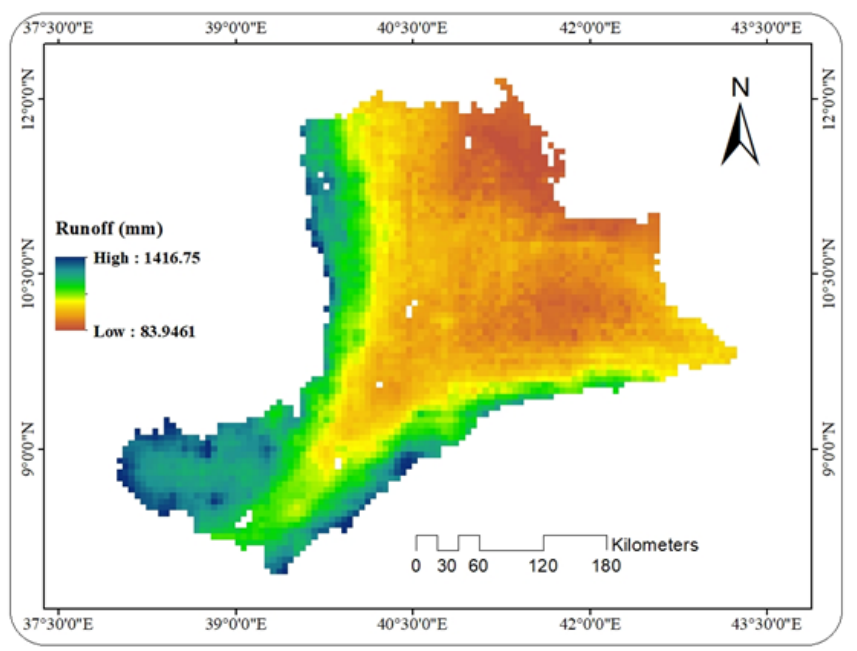

Figure 5 SCS-CN Runoff volume.

\section{Rainfall-runoff correlation analysis}

The scatter plot depicted in Figure (6) shows a strong linear relationship between total annual rainfall and SCS-CN runoff with correlation coefficient of 0.9873 . This correlation coefficient indicates that Awash river basin has high response to rainfall runoff. The results of this project findings agreed with, ${ }^{4}$ who states that $\mathrm{SCS}-\mathrm{CN}$ runoff simulation model has been applicable at basin level; if the correlation coefficient of rainfall and runoff is greater than 0.5. In this case, SCS$\mathrm{CN}$ runoff simulation model is suitable to generate rainfall runoff for Awash river basin with correlation coefficient of 0.9873 or $98.7 \%$ confidence interval.

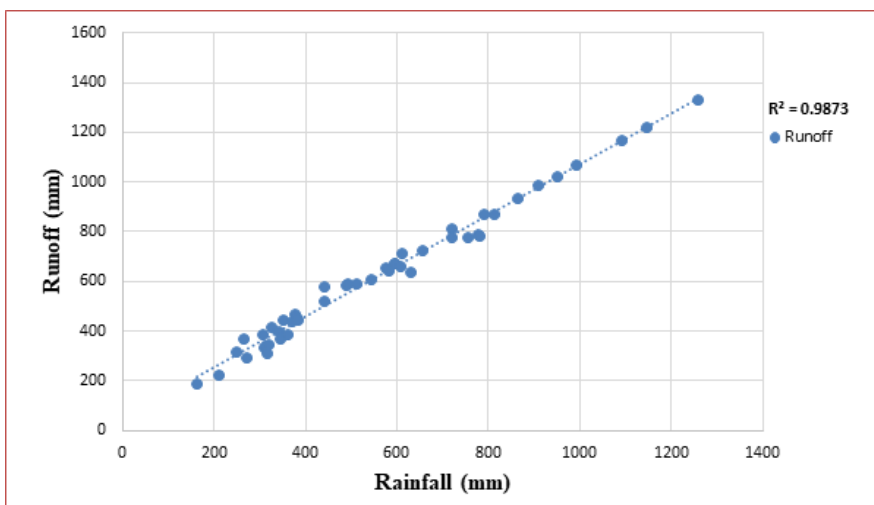

Figure 6 Rainfall-Runoff correlation.

\section{Correlation between observed runoff and predicted runoff from GCN250}

Estimated runoff using SCS-CN model on the basis of GCN250 data was validated with the observed runoff from Awash river basin. It is known from (Figure 7) that the observed runoff and predicted runoff in the study region was significantly corelated with correlation coefficient of 0.9253 for the year 2020. From coefficient of determination (R) value, it is observed that the new GCN250 data product can be considered as effective SCS-CN runoff simulation model input to generate rainfall runoff at basin level in Figure 6, 7. ${ }^{21-23}$

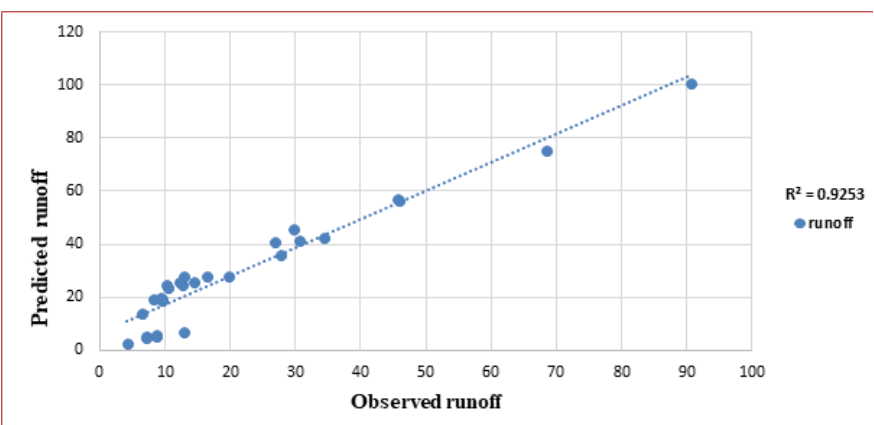

Figure 7 Predicted Runoff-Observed Runoff correlation.

\section{Conclusion}

GIS based SCS-CN runoff simulation model was applied to estimate surface runoff for Awash river basin. The total annual rainfall and Global Curve number (GCN250) were used as inputs in GIS based SCS-CN runoff simulation model. The total annual rainfall of the year 2020 in the study region was $146.73 \mathrm{~mm} /$ year to a maximum of $1,490.99 \mathrm{~mm} / \mathrm{year}$. The GCN250 of the Awash river basin was grouped into three classes, namely; CNI, CNII and CNIII based on five-day Antecedent Soil Moisture Condition (AMC). The average curve number (CNII) values range from 60 to a maximum of 90 and was used to calculate maximum soil water retention potential (S). The curve number values associated with CNI and CNIII range from the lowest 40 and 78 to the highest values of 85 and 98 respectively. On the other hand, maximum soil water retention potential (S) was calculated from average curve number (CNII) and the values are range from the minimum of 16 in built-up areas and to a maximum of 169 in areas covered with agriculture and vegetation. The final surface runoff values for the Awash river were generated on the basis of total annual rainfall and maximum soil water retention potential (S) of the year 2020. Accordingly, a runoff variation that range from $83.95 \mathrm{~mm} /$ year to a maximum of $1,416.75 \mathrm{~mm} /$ year were observed in the study region. A correlation analysis was performed to explain the relationship between total annual rainfall and surface runoff. The relationship between these two variables indicates a strong linear relationship with correlation coefficient of 0.9873 or 98.73 $\%$ confidence interval. Furthermore, rainfall runoff predicted from GCN250 was validated with observed runoff obtained from station gauges in the study region. Predicted runoff was well correlated with observed runoff with correlation coefficient of 0.9253 . From this stand point, it is observed that the new GCN250 data can be used as an input for SCS-CN model to estimate rainfall runoff at basin level.

\section{Acknowledgments}

None.

\section{Conflicts of interest}

The author declares there is no conflict of interest.

\section{References}

1. Patil JP, Sarangi A, Singh OP, et al. Development of a GIS interface for 
estimation of runoff from watersheds. Water Resources Management 2008;22(9):1221-1239.

2. Deshmukh DS, Chaube UC, Ekube Hailu A, et al. Estimation and comparision of curve numbers based on dynamic land use land cover change, observed rainfall-runoff data and land slope. Journal of Hydrology. 2013;492:89-101

3. Li H, Zhang Y, Vaze J, et al. Separating effects of vegetation change and climate variability using hydrological modelling and sensitivity-based approaches. Journal of Hydrology. 2012;420-421:403-418.

4. Al-Ghobari H, Dewidar A, Alataway A. Estimation of surface water runoff for a semi-arid area using RS and GIS-Based SCS-CN method. Water (Switzerland). 2021;12(7):1-16.

5. Sharma A, Kanga S. Surface Runoff Estimation of Sind River Basin Using SCS-CN Method and GIS Technology. Research Square. 2020.

6. Satheeshkumar S, Venkateswaran S, Kannan R. Rainfall-runoff estimation using SCS-CN and GIS approach in the Pappiredipatti watershed of the Vaniyar sub basin, South India. Modeling Earth Systems and Environment. 2017;3(1):1-8.

7. Jan Sitterson, Chris Knightes RP. An Overview of Rainfall-Runoff Model Types An Overview of Rainfall-Runoff Model Types. US Environmental Protection Agency. 2017. p. 29.

8. Vijay P Singh. 123 Computer Models of Watershed Hydrology. Edited by Vijay P. Singh. In Book reviews. 1995;14:1-1.

9. Mckeever V. Hydrology. In National Engineering Handbook (Issue August). 1972.

10. Bhuyan SJ, Mankin KR, Koelliker JK. Watershed-scale amc selection for hydrologic modeling. American Society of Agricultural Engineers. 2003;46(2):303-310.

11. Tirkey AS, Pandey AC, Nathawat MS. Use of high-resolution satellite data, GIS and NRCS-CN technique for the estimation of rainfall-induced run-off in small catchment of Jharkhand India. Geocarto International. 2014;29(7):778-791.
12. Topno A, AK S, RC V. SCS CN Runoff Estimation for Vindhyachal Region using Remote Sensing and GIS. International Journal of Advanced Remote Sensing and GIS. 2015;4(1):1214-1223.

13. Wang X, Liu T, Yang W. Elaboration d'une modèle robuste d'estimation du ruissellement fusionnant la méthoderationnelle et une méthode du SCSCN modifiée. Hydrological Sciences Journal. 2012;57(6):1118-1140.

14. Jaafar HH, Ahmad FA, El Beyrouthy N. GCN250, new global gridded curve numbers for hydrologic modeling and design. Scientific Data. 2019;6(1):1-9.

15. Hailu R, Tolossa D, Alemu G. Water institutions in the Awash basin of Ethiopia: the discrepancies between rhetoric and realities. International Journal of River Basin Management. 2018;16(1):107-121.

16. Berhe FT, Melesse AM, Hailu D, et al. MODSIM-based water allocation modeling of Awash River Basin, Ethiopia. Catena. 2013;109:118-128.

17. FAO and IHE Delft. Water accounting in the Awash River Basin. 2020.

18. Funk C, Peterson P, Landsfeld M, et al. The climate hazards infrared precipitation with stations - A new environmental record for monitoring extremes. Scientific Data. 2015;2:1-21.

19. Mishra SK, Singh VP. Another look at scs-cn method By. Hydrologic Engineering, 2(July). 1999;257-264

20. Mockus V. Section 4: Hydrology. In National Engineering Handbook: Vol. Section 4. 1965. p. 762.

21. Liu X, Li J. Application of SCS model in estimation of runoff from small watershed in loess plateau of China. Chinese Geographical Science. 2008;18(3):235-241.

22. Zhang G, Zhang $\mathrm{X}, \mathrm{Hu} \mathrm{X}$. Runoff and soil erosion as affected by plastic mulch patterns in vegetable field at Dianchi lake's catchment, China. Agricultural Water Management. 2013;122:20-27.

23. Zhao F, Chiew FHS, Zhang L, et al. Application of a macroscale hydrologic model to estimate streamflow across Southeast Australia. Journal of Hydrometeorology. 2012;13(4):1233-1250. 